\title{
Paradigm Shifts in Global Heritage Discourse
}

\author{
Kapila D. Silva, Ph.D. \\ Associate Professor \\ School of Architecture, Design \& Planning \\ University of Kansas \\ 1465 Jayhawk Blvd, Marvin Hall \\ Lawrence, KS 66045, USA. \\ (E) kapilads@ku.edu \\ (T) 1-785-864-1150
}

\begin{abstract}
This essay narrates the evolution of the UNESCO doctrine on cultural heritage, its Eurocentric underpinnings, the concerns of its doctrinal authority, and the course of its decolonization. Three principal themes in current heritage doctrine - universality, significance, and material originality of heritage - clearly represent the occidental thought that primarily frames contemporary conception of heritage. Based on literature review, the essay examines these themes showing (a) their European patrimony and the problems they pose in managing heritage of a diverse geo-cultural context; and (b) how debates within and beyond UNESCO challenged this persistent representation of heritage sites as original, static, and frozen in time and the resultant changes that redefined the discourse and attempted to address the geo-cultural imbalance in the World Heritage List. The essay argues that achieving geo-cultural balance in the World Heritage List does not necessarily promote further paradigm shifts in the heritage discourse. Yet, the List becomes a powerful catalyst to evoke the debate of decolonization globally and, most importantly, locally, by bringing the coloniality of heritage thinking, governance, and practice at the regional, national and local levels of the Global South into focus.
\end{abstract}

Keywords: World Heritage, UNESCO, Cultural Heritage, Decolonizing Knowledge, Euro-centrism

\section{Citation:}

Please contact the author for accurate citation information for this article. 


\section{Introduction}

In 1972, the United Nations Educational, Scientific, and Cultural Organization (UNESCO) introduced the Convention Concerning the Protection of the World Cultural and Natural Heritage. The purpose of this World Heritage Convention is to identify and declare cultural and natural heritage sites around the globe as 'World Heritage', based on their exceptional universal significance and rarity, in order to preserve these significant places for posterity. State Parties (national governments) nominate cultural and natural properties within their national boundaries to be recognized as World Heritage Sites and to be included in the World Heritage List. State Parties are then supposed to conserve and manage these sites, based on the operational guidelines and charters developed by UNESCO and its advisory bodies, the International Council of Monuments and Sites (ICOMOS), the International Union for the Conservation of Nature (IUCN), and the International Centre for the Study of the Preservation and Restoration of Cultural Property (ICCROM). The decision making is vested in the World Heritage Committee, comprised of representatives (mostly composed of ambassadors and government ministers) of twenty-one elected State Parties that are signatory to the Convention. As of October 2014, 161 State Parties have 1007 properties listed as World Heritage. Out of this number, 779 are cultural properties, 197 are natural properties, and 31 are mixed properties (cultural landscapes) (UNESCO, 2014).

For cultural heritage, the operational guidelines for conserving and managing heritage were generated following the principles expounded in the Venice Charter of 1964, which in turn was based on philosophical, political, and conservation sensibilities developed in Europe over several centuries. Consequently the cultural heritage conservation principles and practices developed under the World Heritage Convention became a Eurocentric doctrine, which was adopted to define, preserve, and manage cultural places all over the world. As the formal archaeological practices and related legislation in many countries are still based on those of the colonial era, this Eurocentric doctrine continues to reinforce the status quo of heritage conservation thought and practice around the world.

Laurajane Smith calls this global heritage thinking the Authorized Heritage Discourse (AHD), because of its pervasive hegemonic nature in determining international and national thinking, policies and practice of heritage management. This is achieved through the charters and conventions adopted by UNESCO and ICOMOS. State Parties and national ICOMOS bodies are required to closely follow the values, definitions, norms, and guidelines devised by these charters in order for the heritages in their territories to be recognized as World Heritage (Smith, 2006). She argues that the practice of defining heritage values in terms of 'objective' scientific and aesthetic significance masks the real cultural and political work that defines heritage. Smith (2006) also points out that the technical process propagated by AHD itself is cultural: It looks like an objective technical activity of preserving the physical integrity of a historic place. However, the selective process that defines the site's value and authenticity, as well as the efforts taken to restore that selective history, is a subjective normative socio-political process. This discourse is embedded and institutionalized in primary documents, such as the Venice Charter, the Burra Charter, and the World Heritage Convention; they embody the 'best practices' in heritage management, and hence, these should be considered institutions of AHD. The 
intertextuality of heritage conventions and charters creates a body of self-referential authoritative discourse on heritage management. The power of these documents is also established through the intellectuals and professionals engaged in this process. Acknowledging these ideological biases, legacies, and authorizing mechanisms is critical in making necessary changes to the policies and practices of the global heritage management.

As the cultural heritage of many parts of the world is based on specific native worldviews of what is heritage and how to take care of it, this authorized heritage doctrine runs against such local wisdom and practices. Over the years UNESCO has introduced new charters and conventions and revised the operational guidelines to recognize local ways of perceiving and safeguarding cultural heritage. One can still see the tension between local knowledges and the UNESCO doctrine appearing at multiple levels. Studies of nonWestern heritage sites clearly demonstrate these tensions, some subtle while others more overt. For example, the dominant role played by the non-Western countries in formulating the Convention on Intangible Cultural Heritage and the initial lack of support from European countries in this process have been shown as examples of the dominant Eurocentricism in global conservation practice (Aikawa-Faure, 2009). Some historic places related to European colonialism in the non-Western world are listed as World Heritage Sites and financially supported in order to reinforce the social, economic and political histories of Western elites (Winter 2007). Another issue is how local heritage managers are trapped within the UNESCO doctrine and conservation practices introduced during colonial eras. Decolonizing heritage conservation knowledge has consequently become difficult in these contexts, especially when it is an 'academic' project without the engagement of the local agency (Silva, 2013b).

This essay narrates the evolution of the UNESCO doctrine on cultural heritage, its Eurocentric underpinnings, the concerns of its doctrinal authority, and the course of its decolonization. My focus here is primarily on 'tangible' cultural heritage - the monuments and sites. Other aspects of heritage that come under the UNESCO doctrine such as natural heritage, movable heritage, and 'intangible' cultural heritage are not discussed.

\section{The Occidental Milieu of Global Heritage Doctrine}

The contemporary global doctrine of heritage conservation has European origins in both ideological and historical terms. It is closely tied to the roots of the development of the idea of heritage preservation since classical antiquity, specifically the eighteenth and nineteenth century Enlightenment movement in Europe. Three principal themes in current heritage doctrine - universality, significance, and material originality of heritage - clearly represent the occidental thought that primarily frames the contemporary conception of heritage. I will examine these themes showing their European patrimony and the problems they pose in managing heritage of a diverse geo-cultural context. 


\subsection{The Universality of Heritage}

The fundamental assumption embedded in the idea of World Heritage is that certain cultural expressions across the world could be identified as having universal significance, valued equally by all people of the world irrespective of their geo-cultural differences. This assumption of universalistic cultural heritage is connected to the development of a universal ethos in the West. According to Headley (2007, p. 10), the Western notion of universality "expresses a potentially comprehensive integration or inclusion of all peoples into a broad community, together with the legal and constitutional issues that this process entails". He traces the origins of the concept to the Greek understanding of the known inhabited world or oikoumene, Stoic notions of cosmopolis and universal brotherhood, and to its imperial manifestations in the Roman Empire. He further points out that the evolution of jus naturale, or natural law, was a decisive dimension of the universality notion in Europe. It evolved first as a Christian rendering of the imperial Roman law through the Middle Ages and later as a secularized concept that is common and universal to all humans in the age of Enlightenment. Contemporary concern for global ideals, as in the case of World Heritage, is based upon this Western universalism, propagated through projects of global domination, including colonialism, neocolonialism, and achievements in science and technology (Byrne, 1991; Pohl 2003; Headley, 2007).

The development of the idea of universalistic heritage can be traced to the emergence of the modern conservation movement in Europe in the eighteenth and nineteenth centuries, especially in relation to the consequences of warfare. The thought of a common European heritage was, however, evident even earlier than that during the Italian Renaissance: Restoring monuments of classical antiquity was then derived based on a nostalgic veneration of the lost great civilization of the Roman Empire. As the capital of the European Empire and of Christianity, Rome's monuments represented the 'civilized center' of an otherwise barbaric world. In the Church's desire to show its superiority over paganism, these ancient structures were seen as monuments of Christianity and thus were to be preserved in order to use the legacy of the Roman memory to bring Europe together (Jokilehto, 1986).

A new approach to historical studies that emerged during the Enlightenment created the modern notion of cultural continuity; a linear view of time, which perceived unbroken cultural links between the past and present societies. Monuments of the past were thus considered material evidence of that cultural continuity, representing particular moments in the history of a society (Cleere, 1989). With the evolution of nationalism in European countries in the eighteenth century, the desire to protect national monuments to embody a nation's history became a widespread movement (Jokilehto, 1986). The need was raised for considering remarkable buildings and works of art the common heritage of Europe (and so, of all humanity) and thus for sparing them during wars. This need was recognized at a conference in Brussels in 1874, following the Franco-Russian war; cultural heritage was declared to belong to all nations irrespective of the location of such heritage (Jokilehto, 1986). An international convention drafted at The Hague in 1899 and 1907 recommended the occupying country spare and safeguard the buildings of religious, artistic, scientific and historic importance in the occupied country (Jokilehto, 1986). 
These sentiments, however, could not stop the destruction to Europe's architectural heritage during the First World War.

Following the reconstruction of towns and monuments across Europe in the wake of the war, appropriate principles for conservation of historic monuments were laid down at an international conference in Athens in 1931, organized by the International Museums Office in Paris, the institution charged with the conservation of cultural heritage by the Assembly of the League of Nations. The Athens Conference found that "the question of the conservation of the artistic and archaeological property of mankind is one that interests the community of States, which are wardens of civilization” (ICOMOS, 1931). The Assembly recommended that Member Governments to adopt the resolution and to collaborate to ensure the protection of monuments and works of art. This 'Athens Charter' became the first intergovernmental policy on conservation, marking the launch of formulating international guidelines on conserving cultural heritage, and consequently of strengthening the idea of universal heritage (Jokilehto, 1986). A discourse that was originally about a common European heritage (nevertheless called, that of 'mankind'), devised to claim a unified European identity and cultural continuity, was now expanded to include the rest of the world by the 'Member Governments', which were clearly colonial imperialists.

At the end of the Second World War and with the establishment of the United Nations Organization in 1945, UNESCO was charged with the international cooperation related to matters of culture. Initially, UNESCO's focus on culture was limited to museums. But in the 1950s attention was extended to historic sites and monuments. An International Committee on Monuments was founded in 1951, and ICCROM was established in Rome in 1959 for providing preservation training and expertise to Member States (Jokilehto, 1986). A series of international meetings on the conservation of architectural heritage, held in Florence, The Hague, and Paris under the auspices of UNESCO, led to the Second International Congress of Architects and Technicians of Historic Monuments in Venice in 1964. The resolutions of that Congress gave birth to the International Charter for the Conservation and Restoration of Monuments and Sites or 'The Venice Charter'. The Charter identifies that "[p]eople are becoming more and more conscious of the unity of human values and regard ancient monuments as a common heritage. The common responsibility to safeguard them for future generations is recognized", and recommends that "the principles guiding the preservation and restoration of ancient buildings should be agreed and be laid down on an international basis, with each country being responsible for applying the plan within the framework of its own culture and traditions” (ICOMOS, 1964). The Charter became the primary international document in conservation theory. It framed many regional charters and national legislation worldwide and became the ethical code for ICOMOS, which was established at the same Congress (Jokilehto, 1986).

This gradual evolution of the idea of universalistic heritage culminated in the founding of the World Heritage Convention in 1972. The applicability of a universalistic ideal in relation to cultural heritage has been questioned. Cleere (2001) points out that this thinking "is paradoxical", since "[c]ultural evolution is by its very nature one of diversification", and is "logically applicable only to the earliest phases of human cultural evolution, and perhaps also to the global culture of the late twentieth century” (p. 24). 
Claims to universal heritage seem to rest on two assumptions: one is that people around the world have an intrinsic interest in safeguarding their own heritage; the other is that people of any country share an inherent concern for the heritage of other countries. Neither assumption is necessarily proven, however (Byrne, 1991). The universal ethos of heritage might also be based on the premise that there are no alternative ways of understanding what constitutes cultural heritage (as well as of protecting it), other than one ideal model that transcends the plurality of cultural heritage and of approaches to its protection worldwide.

Imposing a universal claim upon local heritage, particularly by an international body founded by Western powers and based upon Western values, disregards humanity's cultural differences, and thus has imperialist connotations. Porter (2003, p.128) considers making cultural remnants of new nation states the possession of citizens of all nations an ideological shift in the former colonial powers to possess cultures in a "more benevolent but equally paternalistic" manner instead of possessing countries. One may argue that while the contemporary conception of cultural heritage and its management is of European origins, this knowledge has been adapted to fit the local socio-cultural and political contexts of other countries, and therefore has gained universal validity. Such an argument could be misleading. Nations with immense global power impose their own kinds of knowledge over countries under their cultural spheres of influence (Trigger, 1984; Byrne, 1991). Therefore, approaches to cultural heritage protection cannot be free of imperial connotations unless the local heritage practitioners consciously address the ideological impositions in their borrowed knowledge.

The discourse on the universality of heritage is in fact a question regarding the ownership of heritage, the most central issue in heritage management: Who has the right to make decisions about heritage and how to manage it, based on whose ideals and norms? Should it be "the 'owners' of the land, the dispossessed with traditional claims, the local community, the nation or state, or even the world?” (Ucko, 1989, p. xi). Under the World Heritage Convention, national governments are the prime sovereigns of cultural heritage located in their territory, with a mandate to protect and promote such heritage. Inclusion of cultural properties in the World Heritage List requires the State Party's consent (Porter, 2003). A state's hegemony in heritage determination could disenfranchise the local groups from their past and cultural identity. In most cases, the real stakeholders are rarely consulted when making decisions related to their own heritage. Local perceptions of heritage may also be suppressed if they do not appropriately fit the national narrative. Placing universal claims on local heritage through national mechanisms remains an imperialist operation.

The debate between cultural particularism and universality has been an issue since the inception of the World Heritage Convention that led to a process of 'decolonization' of the doctrine. This has occurred through a series of revisions to the Convention's criteria for recognition of properties, to which I will return later. 


\subsection{The Intrinsic Significance of Heritage}

In the World Heritage Convention, the thought of universalistic heritage is encapsulated in the construct of 'Outstanding Universal Value', which is the essential condition for inclusion of a cultural or natural property on the World Heritage List. The concept of value or significance had been used in many European traditions of archaeological conservation as the reason for heritage protection. The significance of a cultural object or place has been understood as a quality inherent in that object or place; therefore, it is assumed that the presence or absence of this essential attribute is factual, immutable, objectively observable, measurable, and verifiable (Tainter and Lucas, 1983; Labadi, 2013). For example, UNESCO's first Operational Guidelines for the Implementation of the World Heritage Convention of 1977 mentions that parts of the world's heritage can be considered to be of Outstanding Universal Value "because of their exceptional qualities" and by "evaluating solely the intrinsic merit of a property" that includes its original form and subsequent modifications, "which in themselves possess artistic or historical values" (UNESCO, 1977, pp. 1-3; emphases added).

This view of significance of cultural property is based on empiricist-positivistic thinking. Origins of this thinking can again be traced to Classical Greek and Medieval thought. Its main propositions were clearly laid out in the eighteenth century and developed in the late nineteenth and early twentieth centuries. Based on an 'atomistic' view, empiricists and positivists believe that all meaning and knowledge consists of primitive terms or statements. These terms can be understood from either direct connection with them through sense experience, or defined with reference to statements that are so understood. The source of meaning and knowledge must thus be intrinsic in the phenomenon being experienced or observed. The knowledge thus derived must be immutable. Such understanding should therefore be empirically verifiable to be meaningful and true. In the empiricist-positivist view, cultural properties either possess or lack an inherent, immutable quality or significance, which evokes our understanding of their importance. The significance is in a cultural property, rather than in our minds (Tainter and Lucas, 1983, pp. 710-712). It has been widely held since the Enlightenment that aesthetic experience is a human predisposition and people form consensus concerning the value of certain works of art (Labadi, 2013).

This view disregards the role culture plays in generating value and meaning for cultural properties, and, in turn, the cultural diversity related to heritage management. There is no value intrinsic to a cultural property (Smith, 2006); values are associated with a property by its cultural group, based on a culturally specific ideological framework, and the attributed values transforms over time across generations. Values vary across cultures as well (Rapoport, 1990). Moreover, association of significance to a cultural property also varies depending upon the difference in heritage conservation theories across time and space; the idea of an absolute value cannot accommodate theoretical change (Tainter and Lucas, 1983). The conception of immutable universal ideals and meanings intrinsic to a cultural property is therefore questionable both in theoretical and practical terms in managing diverse cultural heritage resources worldwide. 


\subsection{The Originality and Materiality of Heritage}

This view of a heritage site possessing intrinsic and immutable values led to the emergence of a particular conservation ethic that searches for and makes efforts to preserve the originality of those values embedded in the materiality of a cultural property. For the World Heritage Convention, the originality or 'truth' about the Outstanding Universal Value of a cultural property is represented in the concept of authenticity. The initial parameters used in the World Heritage designation in its first three decades to test for authenticity included the physical dimensions of a cultural property, i.e., design, materiality, workmanship, and setting, which had been understood as universally applicable. Moreover, the test of authenticity was applicable not only to original form and structure but also to all subsequent modifications and additions, "which in themselves possess artistic or historical values” (UNESCO, 1977, p. 3). The notion of authenticity was thus understood as an objective and measurable attribute inherent in the material fabric of artefacts and monuments (Jones, 2010).

This materialist conception of authenticity is related to the modern conservation ethic, which dictates that the preservation of a historic property should be a minimal intervention to arrest decay and to stabilize the property from further deterioration. That preservation treatment should be reversible, if necessary, to bring the artefact back to its pre-treatment condition; it should not replace the decayed parts, but conserve them; and it should not remove the natural consequences of the ageing of the original materials. However, later accretions should be removed, and not be considered natural patina of the ageing process. If restoration of an artefact is necessary, it should be carried out based on verifiable historical evidence of its original status, without structural, stylistic or decorative falsification (Oddy and Linstrum, 2011). Renovation or reconstruction of a historic property for its protection, therefore, does not have much authentic value in the contemporary conservation ethics.

This conservation ethic is an outcome of a debate on the principles of architectural conservation practices which emerged during the mid-nineteenth century in Europe. The point of contention was the acceptable extent to which historic monuments, mostly churches and cathedrals, were to be restored. While some conservationists supported fullscale restoration, others favoured minimal treatment. The former group, led by French architects under government patronage to restore historic buildings, argued for 'stylistic restoration' of monuments; reinstating a historic building to its completeness even if the outcome may not resemble its original design, in order to sustain a monument's civic and/or religious function. Stylistic and structural falsification and the replacement of historical building material were allowed to regenerate a stylistic unity of a building and its later additions. The latter group, led by English architects, criticized this restoration approach and advocated a 'conservation' or 'minimal intervention' approach that preserves a historic building in its current physical state. They argued for the respect of the original design of a historic monument, preserving its historical authenticity intact, maintaining the aura of antiquity of the building, and avoiding falsification. This 'conservation movement' gradually gained wider acceptance and was received as the modern approach for preserving historic buildings (Jokilehto, 2011). As the Athens Charter of 1931 abandoned stylistic restoration and emphasized the conservation of 
'authentic' historic monuments, this approach became the mainstream conservation practice in Europe (Jokilehto, 1986). Since this philosophy aspired to retain the historical authenticity of a place in its design, materiality, and artisanship, these attributes became the criteria for test of authenticity for World Heritage monuments and sites.

This materialist perspective of authenticity has been criticized for its disregard of cultural factors involved in the idea of authenticity. In this constructivist view, authenticity is a quality that is culturally determined, contextually variable, and observer dependent. Authenticity could thus be determined by cultural values and a multiplicity of attributes (Stovel, 2007, 2008), dynamically negotiated between heritage professionals with different forms of expertise (Jones, 2010; Jones and Yarrow, 2013), and variably understood and constructed by different stakeholders within a community (Silva, 2013a). In many non-Western cultural contexts, symbolic aspects of historic sites - sacred or social significance and associated belief systems and rituals - are culturally more significant than the materiality of the place. In these contexts, traditional practices of taking care of historical buildings may involve restoration, renewal, and reconstruction of those heritage buildings, with the use of new material and design ideas, as long as the buildings' cultural and spiritual values are kept intact (Ito, 1995; Tampeo, 1995; Byrne, 2004, 2014; Chung, 2005; Ariffin, 2013; Chapagain, 2013; Tom, 2013). In some cultural contexts, there may not be any physical evidence of cultural sites retained; rather the evidence is embedded in the memories of them, preserved in the oral histories, songs, and ritual practices (Munjeri, 2004). The materialist approach thus runs counter to such situations where experiential aspects of heritage are vital (Reisinger and Steiner, 2006; Steiner and Reisinger, 2006). In these contexts, the spiritual or associative continuity is therefore more significant than the material continuity of place (Cleere, 1989). In many non-Western contexts, this cultural diversity of how authenticity of heritage is understood has run against the materialist test for authenticity practiced under the World Heritage Operational Guidelines. This points directly at the latter's Eurocentric underpinnings.

\section{Rethinking heritage within UNESCO}

The problematic outcome of this Eurocentric understanding of cultural heritage became increasingly evident by the $1990 \mathrm{~s}$, as the process led to a static, monument-centric, materiality based, and aesthetics oriented version of heritage that is frozen in time. On the one hand, this perspective undermined the dynamic and plural nature of the world's cultural heritage and ongoing social, economic, and political processes behind the recognition of heritage in diverse societies. On the other hand, the distribution of places recognized as World Heritage had become clearly uneven both culturally and geographically by 1997 , the $25^{\text {th }}$ anniversary of the World Heritage Convention, with a high proportion of heritage sites and monuments from Western Europe inscribed on the World Heritage List compared to cultural properties representing other regions of the world (Titchen, 1996).

For example, Cleere (1996, p. 229) mentions that out of the 320 cultural properties inscribed on the World Heritage List by 1994, 154 (48\%) of these sites are in Europe, compared to 67 (21\%) from Asia, 29 (9\%) from Central/South America, and 43 (14\%) representing Africa. Out of the inscribed places, 30\% are archaeological sites, $29 \%$ are 
historical towns of European nature, 20\% are Christian monuments, 3\% are Buddhist monuments, and $2 \%$ are Hindu monuments. The remaining $1 \%$ or less included Islamic and other religious monuments, industrial sites, tombs, symbolic sites, vernacular settlements, and landscapes. Thirty-four (i.e. more than one-third) of the archaeological sites are from the Classical Graeco-Roman period, situated in the countries surrounding the Mediterranean. Having nearly half of the inscribed sites located in Europe "reinforce[s] the view that this is a distribution severely skewed towards a European aesthetic and concept of culture. In other words, the 'values' that are taken into account are largely mainstream European cultural values, with a limited acknowledgement of major non-European cultures (India, China, Pre-Columbian America)” (Cleere, 1996, p. 230).

Furthermore, in an analysis of 106 World Heritage nomination dossiers for sites located in 18 European and non-European countries submitted to UNESCO between 1977 to 2002, Labadi (2013) found that the State Parties predominantly used four authenticity criteria related to the physicality of heritage sites - design, materiality, workmanship, and setting - to represent the authenticity of those sites; they tended to claim that the sites had remained in their original condition since they were first built. Such representations of authenticity overlooked the processes of change in heritage sites over time. These nominations also disregarded the debates over the meaning and universality of these criteria, which ensued from the early 1980s, as well as the importance of multiple measures and the cultural context in defining of authenticity.

Over the years, debates within and beyond UNESCO challenged this persistent representation of heritage sites as original, static, and frozen in time. These challenges question the validity of monument-centric heritage and materiality based ideas of authenticity. For example, heritage experts from Asia formulated a discourse of difference in heritage management for the Asian context. This Asian model is based on a number of distinctive themes that include the importance of local community, spirituality, intangibility, and relative authenticity (Winter, 2012b). Another critical point which came primarily from non-Western countries was to view the heritage as a 'living' or 'continuing' phenomenon rather than a static historical entity. These debates led to gradual multiple changes in the heritage doctrine of UNESCO that began to rethink the Eurocentric notions of the discourse.

\subsection{Rethinking the universality of heritage}

The cultural and regional imbalance in the inscribed World Heritage sites led to a number of steps taken to redefine the concept of universality and to increase the cultural diversity of inscribed heritage sites. The debate on these concepts, associated practices, as well as the steps taken to revise them still ensues, nevertheless.

Even though the idea of universal significance is expressed in the construct of the Outstanding Universal Value (OUV), it was not defined in the 1972 Convention. Six criteria defining OUV for cultural heritage were introduced in 1976, and were revised on multiple occasions (Cleere, 1996; Titchen, 1996). The criteria set the OUV requirements for monuments and groups of buildings from the point of view of history, art, or science, 
and for heritage sites from the historical, aesthetic, ethnological or anthropological points of view (UNESCO, 2013) (See Table 1). The cultural significance defined by these criteria should be "so exceptional as to transcend national boundaries and to be of common importance for present and future generations of all humanity"; and, it is "not intended to ensure the protection of all properties of great interest, importance or value, but only for a select list of the most outstanding of these from an international view point” (UNESCO, 2013, p.14).

The process of determining heritage places that fit these requirements is debatable. On the one hand, the parameters (or 'international view point') used for aesthetic, historical, or scientific judgement are apparently based on Eurocentric values and knowledge categories; appropriateness of such a normative framework for assessing diverse cultural creativity is therefore questionable. On the other hand, the exceptions envisaged by the definition for OUV raise the question whether such heritage places "had to be the 'best of the best' or 'representative of the best'” (Cameron, 2009, p. 129). The original intention of the World Heritage List was to be a limited and exclusive one with about a hundred sites; thus to inscribe the 'best of the best' (Cameron, 2009). As the geo-cultural imbalance of the List became apparent, along with debates about what constitutes heritage and the applicability of existing normative frameworks, the focus moved towards a List containing the 'representative of the best' as well as for a redefinition of what universality of heritage means.

In 1994, UNESCO adopted A Global Strategy for a Representative, Balanced, and Credible World Heritage List. It encourages more countries to become State Parties to the Convention and to prepare lists of sites for tentative nomination. No formal limit is imposed on the total number of sites inscribed on the List (UNESCO, 2013). The concept of OUV has been interpreted as "an outstanding response to issues of universal nature common to or addressed by all human cultures" (Jokilehto, 2006a, p. 2). Six themes are identified as 'issues of universal nature' that represent 'human coexistence with the land' and 'human beings in society' (Labadi, 2005, p. 91). These include: cultural associations (human interactions, symbolic associations, branches of knowledge); expressions of creativity (monuments, sites, and settlements); spiritual responses; movement of people (nomadism, migration, and slavery; routes and systems of transportation); utilization of natural resources (food production, mining, quarrying, and manufacturing); and development of technologies (Jokilehto et.al., 2005; Jokilehto, 2006b). Heritage sites around the world that best represent the outstanding responses to these themes are identified by regional and international groups of experts. State Parties are then encouraged to nominate those sites for inscription.

Moreover, the Global Strategy and its thematic approach had an impact in the revision of some of the criteria used for the definition of OUV of sites. In criterion (i), the original phrase 'unique artistic achievement' was seen as a measure encouraging primarily aesthetic considerations that favour high-style European heritage sites; it was replaced by 'masterpiece of human creative genius' (Cameron, 2009). In criterion (ii), the original phrase 'a nominated property should have exerted great influence' was also thought of favouring colonial values and histories; it was revised to state that 'a nominated property should exhibit an important interchange of human values' (Labadi 2005). Criterion (iii) 
was revised to include 'living' cultural traditions or civilizations, in addition to those that has disappeared (Labadi, 2005; Cameron, 2009).

The outcome of the implementation of the Global Strategy has been listed on UNESCO's website (UNESCO, 2014). Thirty-nine new countries have ratified the Convention in the last ten years, many from small Pacific Island States, Eastern Europe, Africa and Arab States. The number of States Parties who have submitted Tentative Lists for World Heritage status has grown from 33 to 132. Several conferences and thematic studies have been held in Africa, the Pacific and Andean sub-regions, the Arab and Caribbean regions, Central Asia and Southeast Asia, focusing on identifying heritage sites from these regions. In order to improve further the underrepresented categories of sites and geographical coverage, the number of nominations that each State Party is allowed to nominate annually and the number of nominations that will be reviewed every year have been limited.

Nevertheless, since the thematic approach leads to selecting sites that are 'representative of the best', some argue that it lowers the threshold of OUV and makes the determination of 'so exceptional' heritages difficult; it "could potentially inscribe sites that are 'representative of the representative'. At this point, the World Heritage Convention could be at risk of imploding under its weight” (Cameron, 2009, p. 133). The Global Strategy could nevertheless be effective in bringing an equitable representation of heritage from the Global South. For example, certain heritage sites in developing countries are the outcome of colonial legacies; nominations of these sites face tough challenges since they are already represented in the List by similar, yet better built and preserved, sites from their historical colonial masters. Implementation of the thematic approach of the Global Strategy should therefore be viewed within specific regions and countries for the 'representative of the best' rather than from a universalistic perspective.

\subsection{Recognizing the plurality of heritage}

One outcome of the Global Strategy is to identify new categories for World Heritage sites, such as cultural landscapes, industrial heritage, deserts, coastal-marine and smallisland sites, in addition to the original categories of monuments and sites that favored European architectural and urban heritage (UNESCO, 2014). A significant measure was the adoption of the 'cultural landscape' category - defined as significant interactions between people and the natural environment - in 1992; this has successfully opened up the World Heritage List to more cultures and regions, particularly to indigenous communities who maintain special attachment and interactions with the natural environments (Titchen, 1996; Cameron, 2009). Many of the continuing or 'living' heritage sites in the Asia-Pacific region and in Africa could be recognized and inscribed as cultural landscapes. Moreover, some World Heritage sites in Asia such as Borobudur, Ayuttaya or Angkor could be considered cultural landscapes; indeed conservation and management of such heritage sites could benefit from approaching them as cultural landscapes (Miura, 2005; Taylor, 2013).

Another significant change in global heritage doctrine is the recognition in 2003 of the intangible dimensions of cultural heritage, which helped expand the idea of heritage from 
the parochial focus on material forms of heritage, such as monuments and sites, into nonmaterial aspects of heritage that include cultural knowledge, practices, and expressions. The Convention for the Safeguard of the Intangible Cultural Heritage defines this category of heritage as the practices, representations, expressions, knowledge, and skills - as well as the instruments, objects, artefacts and cultural spaces associated therewith that communities, groups and, in some cases, individuals recognize as part of their cultural heritage. It is usually expressed in these forms: oral traditions; performing arts (such as traditional music, dance, and theatre); social practices, rituals and festive events; knowledge and practices concerning nature and the universe; and traditional craftsmanship (UNESCO, 2003). A key factor that led to this Convention was the increasing frustration felt by countries in the Global South that their rich and diverse cultural expressions were hardly reflected in the monument- and material-centric Western perception of cultural heritage and its resultant, imbalanced World Heritage List (Aikawa-Faure, 2009). The Convention challenges this Authorized Heritage Discourse (Smith and Akagawa, 2009; Smith and Waterton, 2009); the discomfort generated was reflected in the fact that some notable Western countries abstained from voting for the Convention (Kurin, 2004; Aikawa-Faure, 2009). Comparable to the World Heritage List, UNESCO now inscribes cultural practices and expressions in the Representative List of Intangible Cultural Heritage of Humanity, most of its inscribed heritages representing non-Western and East-European countries (UNESCO, 2014). Having two separate Conventions and two separate lists for tangible heritage and intangible heritage has generated various conceptual and practical issues in managing cultural heritage, nevertheless (Silva, 2010).

\subsection{Recognizing cultural processes and intangible values in determining heritage authenticity}

Decades of debates on the notion of authenticity and the significance of intangible aspects of heritage led to the Nara Document on Authenticity, which emphasizes the importance of cultural context in assessing the authenticity of heritage properties, and of expanding authenticity judgments beyond a fixed set of criteria, mechanistic formulae, or standardized procedures (ICOMOS, 1994). The Nara Document instead recommends using of a variety of sources of information to define the authenticity of cultural heritage. In addition to the original attributes of form and design, materials and substance, location and settings, aspects of these sources could include the following: use and function; traditions, techniques and management systems; language and other forms of intangible heritage; spirit and feeling; and other internal and external factors (UNESCO, 2013). The Nara Document encourages countries and cultures to develop assessment processes and tools specific to their nature and needs. This approach provides flexibility in assessing authenticity and considers both materiality as well as culture-based constructs of heritage authenticity. For example, many Asian cultures have practiced cyclical restoration or repetitive maintenance of buildings for millennia without much consideration for their material authenticity (Suzuki, 1995). These cultural practices now form a part of accepted practices for heritage management. This is exemplified in the heritage management strategy developed by UNESCO for the Kathmandu Valley heritage sites in Nepal. Named 'Cyclical Renewal', it allows monuments to be dismantled and reconstructed 
rather than preserved in their authentic physical state (UNESCO-Kathmandu Office, 2007a).

Although it took time to materialize, the recognition of these steps created a paradigm shift in the global heritage discourse. They emphasize the significance of local and indigenous knowledge for heritage management. They also broaden the concept and categories of heritage as understood by diverse cultures and point out the importance of intangibility and spiritual dimensions of heritage in addition to its materiality. These steps establish the culturally relative nature of the notion of authenticity of heritage.

\section{Conclusion}

The efforts taken by UNESCO over the past two decades have not necessarily brought the intended representative geo-cultural diversity and balance to the World Heritage List. Europe and North America still dominate the List in terms of the total number of cultural properties inscribed (52\%), as well as of the number of heritage sites inscribed annually (See Tables 2 and 3). Reasons for this continued imbalance go beyond the mere revision of heritage concepts and "objective and scientific considerations" of the World Heritage Committee (UNESCO, 2013, p.6). One difficulty is the limited financial, administrative and human resources in countries of the Global South to prepare heritage inventories, protect heritage, and nominate sites for inscription (Labadi, 2005). Another reason, related to the former, is the lack of understanding and/or knowledge of the Convention, the Global Strategy, and the Operational Guidelines in some countries and their heritage community (Labadi, 2005; Stovel, 2008). Furthermore, heritage governance of most countries in the Global South is still based on the legislation and practices of their colonial era. Changes to the heritage discourse at the global level have not been effectively transferred to the local level (Silva, 2013b). These economic and political reasons are, at least in part, the outcome of relentless colonial and neo-colonial forces still at work.

Frey, Pamini, and Steiner (2013) found that economic and political factors are shown to have a systematic impact on the composition of the World Heritage List. Countries that historically had high GDP, larger populations, and longer years of 'high' civilization dominate the List. Furthermore, the size of the country is positively correlated with the number of sites a country has on the List. While the size of a country is related to its number of Natural Heritage sites, the historical GDP and population, reflecting the historical economic development and the political and cultural potential of a country, are more important for having more Cultural sites listed. Moreover, the tenure of a country being a signatory to the Convention, holding a seat in the World Heritage Committee, and having a permanent or a rotating membership on the UN Security Council are factors strongly correlated to the number of sites inscribed in the List. However, being a rotating member of the Security Council, which should have no relationship to the value of a country's heritage, seems to have a higher impact on having new sites inscribed during that tenure than being a permanent member (Steiner and Frey, 2012). These economic and political factors are primarily related to the colonial and neocolonial global order, and illustrate the invisible and continuing consequences of the colonial legacy. 
UNESCO's response to these neocolonial dynamics has been primarily procedural. Almost two-thirds of the States that are signatories to the Convention had never been elected to the World Heritage Committee. To ensure an equitable geo-cultural representation on the Committee, a number of resolutions have been adopted: to reserve a certain number of seats for State Parties who do not have sites inscribed on the World Heritage List; to invite States to voluntarily reduce their terms of office from six to four years and not seek consecutive terms of office (UNESCO, 2013); and to financially support the heritage experts and representatives from the developing countries on the Committee to increase their participation in the Committee activities (Labadi 2005). However, Steiner and Frey (2012) found that, after the implementation of the Global Strategy, the longer tenured countries obtained relatively more sites than did countries with shorter tenure in the Convention. State Parties with their heritage already wellrepresented are now encouraged to voluntarily suspend, or space over time the submittal of new nominations, or to link their nominations with a nomination presented by a State Party whose heritage is currently underrepresented (UNESCO, 2013). State Parties whose heritage is underrepresented are requested to develop bilateral and multilateral cooperation at the regional level so as to increase their expertise and technical capacity to prepare tentative lists for nomination and safeguarding their heritage (UNESCO, 2013). Continued support for improved heritage management training and practice as well as for preparing nominations is needed for underrepresented countries. The rapid geo-political shifts now taking place at the global level, especially the emerging powers in the Global South, could decentre the neo-colonial dynamics of the World Heritage governance in the future (Winter, 2013, 2014).

Achieving geo-cultural and thematic balance in the World Heritage List does not necessarily help to decolonize the heritage discourse. Yet, the List becomes a powerful catalyst to evoke the debate of decolonization globally and, most importantly, locally, by bringing the coloniality of heritage thinking, governance, and practice at the regional, national and local levels of the Global South into focus. Furthermore, this discussion provides opportunities to reflect upon, contest, and devise new knowledge and methods for heritage management that are culturally appropriate. Formulating alternative discourse of heritage at regional levels needs to continue for further dismantling hegemonic notions of heritage theory and practice. Better results could be gained, however, by challenging the persistent coloniality of heritage thinking at national and local levels (Silva, 2013b). This requires changes in instructional cultures and professional elitism in the disciplines of heritage management at national levels. Nominations of sites to the World Heritage List should go beyond the search for global recognition and tourism income and be taken as opportunities to rethink national policies on heritage and its protection. Finally, it is critical to recognize that empowering and engaging the local agency - local communities, indigenous communities, and heritage managers of lower tiers in particular - is more effective in developing culturallyresponsive approaches to heritage conservation, management, and governance. 


\section{References}

Aikawa-Faure, N. (2009). From the Proclamation of Masterpieces to the Convention for the Safeguarding of Intangible Cultural Heritage. In L. Smith \& N. Akagawa (Eds.), Intangible heritage (pp. 13-44). London, UK: Routledge.

Ariffin, S. I. (2013). Islamic perspectives and Malay notions of heritage conservation. In K. D. Silva \& N. K. Chapagain (Eds.), Asian heritage management: Contexts, concerns, and prospects (pp. 65-84). London, UK: Routledge.

Byrne, D. (1991). Western hegemony in archaeological heritage management. History and Anthropology, 5, 269-276.

Byrne, D. (2004). Chartering heritage in Asia's postmodern world. Conservation: The Getty Conservation Institute Newsletter, 19(2), 16-19.

Byrne, D. (2014). Counterheritage: Critical perspectives on heritage conservation in Asia. London, UK: Routledge.

Cameron, C. (2009). The evolution of the concept of Outstanding Universal Value. In N. Stanley-Price \& J. King (Eds.), Conserving the authentic: Essays in honour of Jukka Jokilehto (pp. 127-136). Rome, Italy: ICCROM.

Chapagain N. K., (2013). Heritage conservation in the Buddhist context. In K. D. Silva \& N. K. Chapagain (Eds.), Asian heritage management: Contexts, concerns, and prospects (pp. 49-64). London, UK: Routledge.

Chung, S-J. (2005). East Asian values in historic conservation. Journal of Architectural Conservation, 11(1/March), 55-70.

Cleere, H. (1989). Introduction: the rationale of archaeological heritage management. In H. F. Cleere (Ed)., Archaeological heritage management in the modern world. One World Archaeology 9 (pp. 1-19). London, UK: Unwin Hyman.

Cleere, H. (1996). The concept of 'outstanding universal value' in the World Heritage Convention. Conservation and Management of Archaeological Sites, 1(4), 227-233.

Cleere, H. (2001). The uneasy bedfellows: Universality and cultural heritage. In R. Layton, P. G. Stone, \& J. Thomas (Eds.), Destruction and conservation of cultural property (pp. 22-29). London, UK: Routledge.

Frey, B. S., Pamini, P., \& Steiner, L. (2013). Explaining the World Heritage List: An empirical study. International Review of Economics, 60, 1-19.

Headley, J. M. (2007). Western exceptionalism and universality revisited. Historically Speaking, 9(2), November/December, 9-12. 
ICOMOS (1931). The Athens Charter for the restoration of historic monuments. Paris, France: ICOMOS. Retrieved from http://www.icomos.org/en/charters-and-texts/179articles-en-francais/ressources/charters-and-standards/167-the-athens-charter-for-therestoration-of-historic-monuments

ICOMOS (1964). International Charter for the conservation and restoration of monuments and sites (The Venice Charter), Paris, France: ICOMOS. Retrieved from http://www.icomos.org/charters/venice_e.pdf

ICOMOS (1994). The Nara document on authenticity, Paris, France: ICOMOS. Retrieved from http://www.icomos.org/charters/nara-e.pdf

Ito, N. (1995). “Authenticity” inherent in cultural heritage in Asia and Japan. In K. E. Larsen (Ed.), Nara Conference on authenticity in relation to the World Heritage Convention (pp. 35-46). Paris, France \& Rome, Italy: ICCROM, ICOMOS and UNESCO.

Jokilehto, J. (1986). A history of architectural conservation: The contribution of English, French, German and Italian thought towards an international approach to the conservation of cultural property, D.Phil Thesis, England: The University of York.

Jokilehto, J. (2006a). Considerations on authenticity and integrity in World Heritage context. City \& Time, 2(1), 1-16. Retrieved from http://www.ct.ceci-br.org

Jokilehto, J. (2006b). World Heritage: Defining the Outstanding Universal Value context. City \& Time, 2(2), 1-10. Retrieved from http://www.ct.ceci-br.org

Jokilehto, J. (2011). A history of architectural conservation. $2^{\text {nd }}$ Edition. London, UK: Routledge.

Jokilehto, J., Cleere, H., Denyer, S., \& Petzet, M. (2005). The World Heritage List: Filling the gaps - an action plan for the future. Paris, France: ICOMOS.

Jones, S. (2010). Negotiating authentic objects and authentic selves: Beyond the deconstruction of authenticity. Journal of Material Culture, 15(2), 181-203.

Jones, S. \& Yarrow. T. (2013). Crafting authenticity: An ethnography of conservation practice. Journal of Material Culture, 18(1), 3-26.

Kurin, R. (2004). 'Safeguarding Intangible Cultural Heritage in the 2003 UNESCO Convention: A critical appraisal’. Museum International, 56 (1-2), 66-77.

Labadi, S. (2005). A review of the Global Strategy for a balanced, representative, and credible World Heritage List 1994-2004. Conservation and Management of Archaeological Sites, 7(2), 89-102. 
Labadi, S. (2013). UNESCO, cultural heritage, and Outstanding Universal Value: Valuebased analysis of the World Heritage and Intangible Cultural Heritage Conventions. Lanham, MD: AltaMira Press.

Miura, K. (2005). Conservation of a 'living heritage site': A contradiction in terms? A case study of Angkor World Heritage Site. Conservation and Management of Archaeological Sites, 7, 3-18.

Munjeri, D. (2004). Tangible and intangible heritage: From difference to convergence. Museum International. 56(1-2), 12-20.

Oddy, A., and Linstrum, D. (2011). Series Editors' Preface. In Jukka Jokilehto (2011) A history of architectural conservation (pp. xi $-\mathrm{xii}), 2^{\text {nd }}$ Edition. London, UK: Routledge.

Pocock, C. (2006). Authenticity in cultural heritage management and tourism. Historic Environment, 19(2), 3-8.

Pohl, K-H (2002). Chinese and Western Values: Reflections on a cross-cultural dialogue on a universal ethics. In Rolf Elberfeld \& Günter Wohlfart (Eds.), Komparative Ethik: Das gute leben zwischen den kulturen (pp. 213-232). Köln, Germany: Académie du Midi.

Porter, G. D. (2003). Unwitting Actors: The preservation of Fez's cultural heritage. Radical History Review, 86 (spring), 123-148.

Rapoport, A. (1990). The meaning of the built environment: A nonverbal communication approach. $2^{\text {nd }}$ Edition. Tucson, AZ: The University of Arizona Press.

Silva, K. D. (2010). Tangible and intangible heritages: The crisis of official definitions. Housing and Building Research Journal, 6(3), 12-18.

Silva, K. D. (2013a). The city imageability: A framework for defining urban heritage dimensions. In K. D. Silva \& N. K. Chapagain (Eds.), Asian heritage management: Contexts, concerns, and prospects (pp. 325-344). London, UK: Routledge.

Silva, K. D. (2013b). Epilogue: Prospects for Asian heritage management. In K. D. Silva \& N. K. Chapagain (Eds.), Asian heritage management: Contexts, concerns, and prospects (pp. 345-355). London, UK: Routledge.

Smith, L. (2006). Uses of heritage. London, UK: Routledge.

Smith, L., \& Akagawa, N. (Eds.) (2009). Introduction. Intangible heritage (pp. 1-9). London, UK: Routledge.

Smith, L. \& Waterton, E. (2209). 'The envy of the world?' Intangible heritage in England. In Smith, L., \& Akagawa, N. (Eds.) Intangible heritage (p. 289-302). London, UK: Routledge. 
Steiner, L., \& Frey, B. S. (2012). Correcting the imbalance of the World Heritage List: Did the UNESCO strategy work? Journal of International Organizational Studies, 3, 2540.

Stovel, H. (2007). Effective use of authenticity and integrity as World Heritage qualifying conditions. City \& Time, 2(3), 21 - 36. Retrieved from http://www.ct.cecibr.org

Stovel, H. (2008). Origins and influence of the Nara Document on Authenticity. APT Bulletin, 39(2/3), 9-17.

Suzuki, H. (1995). Authenticity of setting in the cyclical culture. In K. E. Larsen (Ed.), Nara Conference on authenticity in relation to the World Heritage Convention (pp. 399401). Paris, France \& Rome, Italy: ICCROM, ICOMOS and UNESCO.

Tainter, J. A., \& Lucas, G. J. (1983). Epistemology of the significance concept. American Antiquity, 48(4), 707-719.

Tamepo, E. (1995). Maori authenticity and cultural diversity in New Zealand (Aotearoa). In K. E. Larsen (Ed.), Nara Conference on authenticity in relation to the World Heritage Convention (pp. 167-174). Paris, France \& Rome, Italy: ICCROM, ICOMOS and UNESCO.

Taylor, K. (2013). The challenges of the cultural landscape construct and associative intangible values in an Asian context. In K. D. Silva \& N. K. Chapagain (Eds.), Asian heritage management: Contexts, concerns, and prospects (pp. 189-212). London, UK: Routledge.

Titchen, S. M. (1996). On the construction of 'outstanding universal value': Some comments on the implementation of the 1972 UNESCO World Heritage Convention. Conservation and Management of Archaeological Sites, 1(4), 235-242.

Tom, B. (2013). Jiirnnoddharana: The Hindu philosophy of conservation. In K. D. Silva \& N. K. Chapagain (Eds.), Asian heritage management: Contexts, concerns, and prospects (pp. 35-48). London, UK: Routledge.

Trigger, B. G. (1984). Alternative archaeologies: Nationalist, colonialist, imperialist. Man, 19(3/September), 355-370.

Ucko, P. J. (1989). Foreword. In H. F. Cleere (Ed.), Archaeological heritage management in the modern world. One World Archaeology 9 (pp. ix-xiv). London, UK: Unwin Hyman.

UNESCO (1972). Convention concerning the protection of the World Cultural and Natural Property (WHC.2004/WS/2). Paris, France: UNESCO World Heritage Center. 
UNESCO (1997). Operational guidelines for the implementation of the World Heritage Convention. Paris, France: UNESCO World Heritage Center. Retrieved from http://whc.unesco.org/archive/out/opgu77.htm

UNESCO (2003). Convention for the safeguard of the Intangible Cultural Heritage. Paris, France: UNESCO World Heritage Center.

UNESCO (2005). Operational guidelines for the implementation of the World Heritage Convention (WHC.05/2). Paris, France: UNESCO World Heritage Center. Retrieved from http://whc.unesco.org/archive/opguide05-en.pdf

UNESCO (2013). Operational guidelines for the implementation of the World Heritage Convention (WHC.13/01). Paris, France: UNESCO World Heritage Center. Retrieved from http://whc.unesco.org/archive/opguide13-en.pdf

UNESCO (2014). UNESCO Website; online: Retrieved from http://whc.unesco.org/en/globalstrategy/

UNESCO Kathmandu Office (2007). Kathmandu Valley World Heritage Site: Integrated management framework. Kathmandu: UNESCO and Department of Archaeology of Nepal.

Winter, T. (2007). Post-conflict heritage, postcolonial tourism: Culture, politics and development at Angkor. London, UK: Routledge.

Winter, T. (2012). Beyond Eurocentricism? Heritage conservation and the politics of difference. International Journal of Heritage Studies, iFirst Article, 1-15.

doi: http://dx.doi.org/10.1080/13527258.2012.736403

Winter, T. (2013). Heritage studies and the privileging of theory. International Journal of Heritage Studies, iFirst Article, 1-17.

doi: http://dx.doi.org/10.1080/13527258.2013.798671

Winter, T. (2014). Heritage conservation future in an age of shifting global power. Journal of Social Archaeology, 1-21. 
Table 1: Selection Criteria for World Heritage Sites

(Source: UNESCO 2013 Operational Guidelines)

\section{For Cultural Sites (in most cases)}

(i) to represent a masterpiece of human creative genius;

(ii) to exhibit an important interchange of human values, over a span of time or within a cultural area of the world, on developments in architecture or technology, monumental arts, town-planning or landscape design;

(iii) to bear a unique or at least exceptional testimony to a cultural tradition or to a civilization which is living or which has disappeared;

(iv) to be an outstanding example of a type of building, architectural or technological ensemble or landscape which illustrates (a) significant stage(s) in human history;

(v) to be an outstanding example of a traditional human settlement, land-use, or sea-use which is representative of a culture (or cultures), or human interaction with the environment especially when it has become vulnerable under the impact of irreversible change;

(vi) to be directly or tangibly associated with events or living traditions, with ideas, or with beliefs, with artistic and literary works of outstanding universal significance. (The Committee considers that this criterion should preferably be used in conjunction with other criteria);

\section{For Natural Sites (in most cases)}

(vii) to contain superlative natural phenomena or areas of exceptional natural beauty and aesthetic importance;

(viii) to be outstanding examples representing major stages of earth's history, including the record of life, significant on-going geological processes in the development of landforms, or significant geomorphic or physiographic features;

(ix) to be outstanding examples representing significant on-going ecological and biological processes in the evolution and development of terrestrial, fresh water, coastal and marine ecosystems and communities of plants and animals;

(x) to contain the most important and significant natural habitats for in-situ conservation of biological diversity, including those containing threatened species of outstanding universal value from the point of view of science or conservation. 
Table 2: Number of World Heritage Properties by Region (as of October 2014)

\begin{tabular}{|l|r|r|r|r|r|r|}
\hline Region & $\begin{array}{l}\text { Cultural } \\
\text { Properties }\end{array}$ & $\begin{array}{l}\text { Natural } \\
\text { Properties }\end{array}$ & $\begin{array}{l}\text { Mixed } \\
\text { Properties }\end{array}$ & Total & \% & $\begin{array}{l}\text { State } \\
\text { Parties } \\
\text { with } \\
\text { inscribed } \\
\text { properties }\end{array}$ \\
\hline $\begin{array}{l}\text { Latin America \& the } \\
\text { Caribbean }\end{array}$ & 91 & 36 & 4 & 131 & $13 \%$ & 26 \\
\hline $\begin{array}{l}\text { Europe \& North } \\
\text { America }\end{array}$ & 408 & 61 & 10 & 479 & $48 \%$ & 50 \\
\hline Asia and the Pacific & 161 & 59 & 11 & 231 & $23 \%$ & 34 \\
\hline Arab States & 71 & 4 & 2 & 77 & $8 \%$ & 18 \\
\hline Africa & 48 & 37 & 4 & 89 & $9 \%$ & 33 \\
\hline & & & & & & $\mathbf{1 6 1}$ \\
\hline Total & $\mathbf{7 7 9}$ & $\mathbf{1 9 7}$ & $\mathbf{3 1}$ & $\mathbf{1 0 0 7}$ & $\mathbf{1 0 0 \%}$ & \\
\hline
\end{tabular}

Source: http://whc.unesco.org/en/list/stat ( accessed 15 October 2014)

Table 3: Number of Properties inscribed by Region over time (as of October 2014)

\begin{tabular}{|c|c|c|c|c|c|}
\hline \multirow[t]{2}{*}{ Regions } & \multicolumn{4}{|c|}{10 year periods } & \multirow{2}{*}{$\begin{array}{l}\text { Total numbe } \\
\text { of properties }\end{array}$} \\
\hline & $\begin{array}{c}1978- \\
1987\end{array}$ & $\begin{array}{c}1988- \\
1997\end{array}$ & $\begin{array}{c}1998- \\
2007\end{array}$ & $\begin{array}{c}2008- \\
2014\end{array}$ & \\
\hline $\begin{array}{l}\text { Europe \& North } \\
\text { America }\end{array}$ & 132 & 143 & 138 & 66 & 479 \\
\hline Asia \& the Pacific & 46 & 63 & 65 & 57 & 231 \\
\hline $\begin{array}{l}\text { Latin American } \\
\text { Countries }\end{array}$ & 36 & 35 & 46 & 14 & 131 \\
\hline Arab States & 39 & 11 & 13 & 14 & 77 \\
\hline Africa & 33 & 13 & 28 & 15 & 89 \\
\hline
\end{tabular}

